from our Washington Correspondent

IN the past few days, the Nixon Administration has come close to capitulation in its struggle with Senator Kennedy's health subcommittee to preserve the National Institutes of Health from dismemberment. Kennedy, against the almost unanimous advice of the scientific community, has been pushing a proposal to take the National Cancer Institute out of the NIH and establish it as a separate agency.

Last week it became apparent that the Administration has agreed to legislation that is tantamount to acceptance of the Kennedy plan. In return, the major concession made by the Kennedy side is that the proposal will be put before Congress in the Administration's name, not Kennedy's.

If the deal is accepted by the health subcommittee at its meeting this week, the Administration will, it seems, be conniving at an arrangement that may ultimately dissolve the National Institutes of Health, unbalance and fragment the biomedical research endeavour, and delay the date at which unconquered diseases, including cancer, are overcome. The advantage of the compromise, however, is that the Administration will succeed in barring Kennedy, seen in the White House as a potential contender in 1972, from taking credit for what politicians on both sides have presented as a major advance against cancer.

The existence of the compromise was revealed, apparently by accident, at a public hearing last week before the Senate health subcommittee, thus affording an unusual insight into the way Congressional committees conduct part of their business behind the scenes. Elliot L. Richardson, Secretary of the Department of Health, Education and Welfare, of which the NIH is a part, was appearing before the subcommittee to testify in favour of a counterproposal put forward by the Administration on May 11 . The counterproposal, in the form of a bill introduced by the senior Republican member of the subcommittee, Senator Peter H. Dominick, embodies the plan announced by President Nixon last month (see Nature, May 14, 1971).

Nixon's plan would have instituted a "Cancer Cure Program" under which the National Cancer Institute would have had its own budget and director but remain within the NIH ; in addition, the President could have redelegated his authority for the programme back to the Secretary of
Health, Education and Welfare-a stipulation that would in effect have allowed matters to stay as they are.

Richardson arrived at last week's hearing with testimony to explain why this plan (referred to as S.1828, from the number assigned to Senator Dominick's bill) made better sense from the medical and administrative points of view than the bill proposed by Senator Kennedy (designated S.34). Senator Gaylord Nelson, a member of the subcommittee opposed to the Kennedy proposal, started to question Richardson on the Administration's position but it soon became apparent that the document Nelson held in his hand represented a different Administration position from that described by Richardson.

It turned out that Nelson was reading from a private compromise drawn up a few days previously between staff members of the health subcommittee and Administration representatives. The compromise, dated June 8 , was in the form of a bill to be introduced by Senator Dominick and to replace the bill he had introduced on May 11 embodying the Administration's counterproposals. (Dominick, as it happened, had not even seen the new bill drawn up in his name.)

The compromise bill is subject to change until voted on by the health subcommittee at a meeting which is scheduled to take place this week and would not ordinarily have become public until then. But it seems that both the Kennedy side and the Administration are agreed on the main terms of the compromise, which are "to establish a Conquest of Cancer Agency as an independent agency".

The compromise bill adds the phrase "within the NIH", but these words seem to be intended in a purely geographic sense. The compromise is in fact an amalgam of the Kennedy and Administration bills, S.34 and S.1828 respectively, which takes the number of S.1828 (meaning that it is an Administration bill) and the text of S.34. The clause in the original version of S.1828, which allowed the President to redelegate his responsibility for the authority to the Secretary of HEW, has been struck out from the compromise version.

Administration sources claim that the President may delegate his authority anyway, whether the bill allows him to or not, but this interpretation is likely to be resisted by the Kennedy side.
Apart from the question of redelegation, the compromise which the Administration has agreed to is almost word for word identical with the Kennedy bill to set up an independent cancer agency. By revealing the terms of the compromise bill, Nelson put Richardson in the ironical position of having testified in favour of a position

\section{Dark Undercurrents}

A SIGNIFICANT statement against the proposal to institute an independent cancer agency was made before the health subcommittee last week by John A. D. Cooper, president of the Association of American Medical Colleges. Cooper warned of the "dark undercurrents of opinion which appear to be sweeping the national debate on the conquest of cancer into potentially dangerous waters". Such undercurrents included the belief that the key to conquering cancer "lies in the managerial efficiency and capacity of the medical-industrial complex". Cooper's warning was doubtless a reference to the industrial interest-and hence political pressure - with which the new agency as envisaged by the Kennedy Bill would become entrammelled. Apart from the large sums of money to be spent on building new cancer centres, the Kennedy Bill-and the new compromise - explicitly enjoins the new agency to "encourage and coordinate cancer research by industrial concerns". The stark truth, Cooper reminded the subcommittee, is that science is complicated and "the key to its secrets is not neatly wrapped, awaiting discovery, in an appropriations bill or in the medicalindustrial complex".

Cooper also expressed deep concern over "the precedent that would be set by making the director of the program a presidential appointee requiring the advice and consent of the senate. This would seem to imply that the direction of the major research programmes of the NIH is basically a policy rather than a scientific function and thus a matter for political determination". 